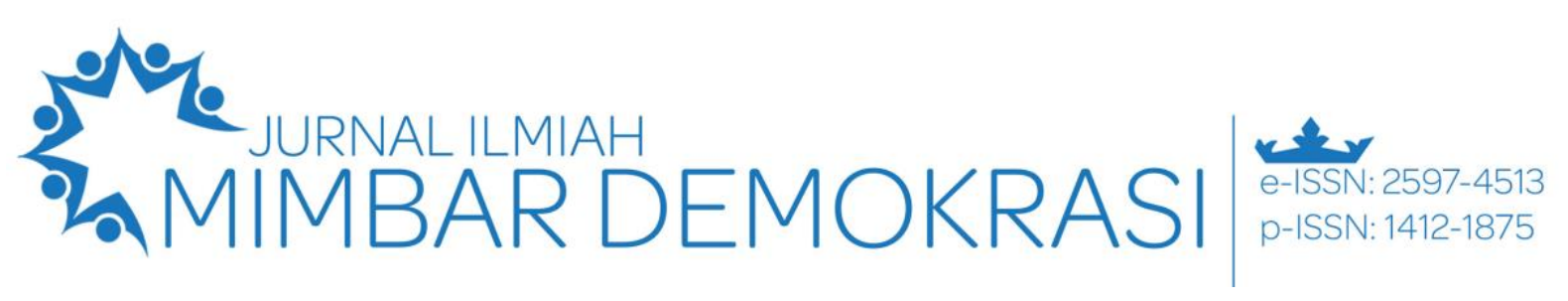

Vol. 20 No. 1 Tahun 2020 | Hal. 11 - 21

\title{
Implementasi permendikbud no.44 tahun 2019 tentang sistem zonasi pada penerimaan peserta didik baru tahun 2020
}

\author{
Amelia Haryanti a, 1*, Dindin b, 2 \\ a Universitas Pamulang, Indonesia \\ b Universitas Pamulang Indonesia \\ 1 dosen00811@unpam.ac.id*; 2dosen02573@unpam.ac.id \\ *korespondensi penulis
}

\begin{tabular}{l}
\hline Informasi artikel \\
\hline Diterima: \\
9 Agustus 2020 \\
Disetujui: \\
1 Oktober 2020
\end{tabular}

Kata kunci: Permendikbud Sistem zonasi PPDB Peserta Didik

\begin{abstract}
ABSTRAK
Tujuan dilaksanakannya penelitian ini adalah untuk mengetahui implementasi kebijakan Permendikbud No. 44 Tahun 2019 tentang sistem zonasi pada PPDB di Kota Tangerang Selatan dalam upaya melaksanakan pemerataan kualitas dan mutu Pendidikan. Penelitian ini dilakukan selama pelaksanaan PPDB tahun 2020 antara bulan Mei 2020 sampai dengan Juli 2020. Penelitian ini menggunakan pendekatan kualitatif dengan metode studi kasus. Subjek penelitian yakni, kepala SMPN, Kasi Kurikulum SMP dan orang tua calon peserta didik. Teknik pengumpulan data menggunakan observasi, wawancara, dan dokumentasi. Hasil penelitian adalah sebagai berikut: Pelaksanaan PPDB tahun 2020 untuk jenjang tingkat SMP Negeri di kota Tangerang Selatan sudah mengacu pada peraturan Permendikbud No. 44 Tahun 2019, sedangkan faktor penghambat dalam pelaksanaan Permendikbud ini adalah daya tampung sekolah negeri yang belum dapat memenuhi kebutuhan lulusan, serta masih banyaknya calon wali murid yang belum memahami diberlakukannya sistem zonasi. Untuk mengatasi permasalahan tersebut, pemerintah daerah bekerjasama dengan dinas pendidikan setempat meningkatkan sarana dan prasarana sekolah negeri dan melakukan sosialisasi tentang sistem zonasi kepada masyarakat jauh-jauh hari sebelum pelaksanaan PPDB
\end{abstract}

\begin{abstract}
Permendikbud No. 442019 implementation concerning the zoning system for the 2020 student admission. The purpose of carrying out this research is to determine the implementation of Permendikbud No. 44 of 2019 concerning the Zoning System in PPDB for the First Middle School level in the City of South Tangerang in an effort to distribute the quality and quality of education. This research was conducted during the implementation of PPDB 2020 between May 2020 and July 2020. This research used a qualitative approach with a case study method. The research subjects were the head of the Junior High School, the Head of Junior High School Curriculum and the parents of prospective students. Data collection techniques using observation, interviews, and documentation. The results of the study are as follows: Implementation of PPDB in 2020 for the level of SMP Negeri in South Tangerang city has referred to Regulation of Permendikbud No. 44 of 2019, while the inhibiting factors in implementing this Permendikbud are the capacity of state schools that have not been able to meet the needs of graduates, and there are still many prospective student guardians who do not understand the implementation of the zoning system. To overcome this problem, the local government collaborates with the local education office to improve public school facilities and infrastructure and conduct socialization about the zoning system to the community long before PPDB implementation.
\end{abstract}

Copyright (C) 2020 (Amelia Haryanti \& Dindin). All Right Reserved

How to Cite: Haryanti, A. \& Dindin. (2020). Implementasi Permendikbud No. 44 Tahun 2019 tentang sistem zonasi pada Penerimaan Peserta Didik Baru Tahun 2020. Jurnal Ilmiah Mimbar Demokrasi, 20(1), 11 21. DOI: $10.21009 /$ jimd.v20i01.16512 
This work is licensed under a Creative Commons Attribution-ShareAlike 4.0 International License. Allows readers to read, download, copy, distribute, print, search, or link to the full texts of its articles and allow readers to use them for any other lawful purpose. The journal hold the copyright.

\section{Pendahuluan}

Kualitas dan mutu Pendidikan yang baik merupakan dambaan bagi seluruh masyarakat dunia, begitu pula dengan kita masyarakat Indonesia. Meningkatnya kualitas Pendidikan akan membentuk masyarakat Indonesia menjadi sumber daya yang mampu bersaing dengan masyarakat dunia. Hal inilah yang menjadikan masyarakat Indonesia semakin menyadari bahwa melanjutkan Pendidikan ke jenjang lebih tinggi merupakan suatu keharusan. Dengan melanjutkan Pendidikan ke jenjang yang lebih tinggi akan semakin mengasah kemampuan dan mengembangkan minat peserta didik untuk mengembangkan potensi yang dimilikinya. Pendidikan yang bermutu dan berkualitas merupakan kebutuhan yang sangat penting bagi masyarakat Indonesia, oleh karena itu pemerintah berkewajiban untuk melakukan perbaikanperbaikan pada setiap sektor pendidikan.

Semakin meningkatnya kesadaran masyarakat akan pentingnya Pendidikan yang bermutu dan berkualitas, menjadikan pemerintah untuk berkewajiban menyediakan dan memfasilitasi Pendidikan yang berkualitas dan bermutu bagi masyarakat. Hal ini tercantum dalam Undang-Undang Sistem Pendidikan Nasional pasal 11 butir (1) yang berbunyi: "Pemerintah dan Pemerintah daerah wajib memberikan Pendidikan yang layak dan kemudahan, serta menjamin terselenggaranya Pendidikan yang bermutu bagi setiap warganegaranya tanpa diskriminasi." Selain tercantum dalam Undang-Undang Sistem Pendidikan Nasional, hak untuk mendapatkan Pendidikan bagi seluruh warganegara juga dimuat dalam Undang-Undang Dasar 1945 Pasal 31 (1) "Setiap warga negara berhak mendapat Pendidikan, (2) Setiap warga negara wajib mengikuti pendidikan dasar dan pemerintah wajib membiayainya. (3) Pemerintah mengusahakan dan menyelenggarakan satu sistem pendidikan nasional, yang meningkatkan keimanan dan ketakwaan serta ahlak mulia dalam rangka mencerdaskan kehidupan bangsa, yang diatur dengan undang-undang. (4) Negara memprioritaskan anggaran pendidikan sekurangkurangnya dua puluh persen dari anggaran pendapatan dan belanja negara serta dari anggaran pendapatan dan belanja daerah untuk memenuhi kebutuhan penyelenggaraan pendidikan nasional. (5) Pemerintah memajukan ilmu pengetahuan dan teknologi dengan menunjang tinggi nilai-nilai agama dan persatuan bangsa untuk kemajuan peradaban serta kesejahteraan umat manusia". (Nurjamila siregar, 2019).

'Dalam sistem zonasi pendidikan maka fungsi dan tujuan pengelolaannya adalah percepatan pemerataan mutu pendidikan pada satuan-satuan pendidikan di Indonesia. Zonasi Pendidikan diawali dengan terbitnya Peraturan Menteri Pendidikan dan Kebudayaan Nomor 17 Tahun 2017 tentang Penerimaan Peserta Didik Baru pada Taman Kanak-kanak, Sekolah Dasar, Sekolah Menengah Pertama, Sekolah Menengah Atas, Sekolah Menengah Kejuruan, atau bentuk lain yang sederajat menjadi dasar pengembangan sistem zonasi pada isu pendidikan lainnya"(Purwanti et al., 2019). Pada pelaksanaan PPDB tahun 2020, peraturan PPDB Zonasi diperbaharui menjadi Peraturan Menteri Pendidikan dan Kebudayaan Nomor 44 Tahun 2019, hal ini dilakukan oleh pemerintah agar tidak ada lagi dikotomi mengenai sekolah unggulan dan bukan unggulan. Pelaksanaan PPDB dengan sistem zonasi saat ini sudah dilaksanakan di seluruh sekolah negeri di Indonesia, tidak terkecuali di Kota Tangerang Selatan, hal ini penting dilakukan mengingat di Kota Tangerang Selatan ini masih banyak persepsi dari wali calon siswa mengenai dikotomi sekolah unggulan dan bukan unggulan, walaupun antara domisili dan sekolahnya berjauhan, selain itu dengan diberlakukannya Permendikbud ini akan meningkatkan kualitas dan mutu pendidikan di Kota Tangerang Selatan. Penelitian yang terkait dengan judul ini pernah dilakukan oleh Novrian Satria Perdana dengan judul Implementasi PPDB Zonasi dalam upaya pemerataan akses dan mutu pendidikan, yang dimuat pada jurnal Pendidikan Glasser No 1 Volume 3 April Tahun 2019. Yang dibahas dalam penelitian ini adalah difokuskan pada pemerataan akses domisili dengan sekolah untuk meningkatkan pemerataan kualitas dan mutu pendidikan.

Berdasarkan pemaparan di atas, berkaitan dengan peningkatan kualitas dan mutu 


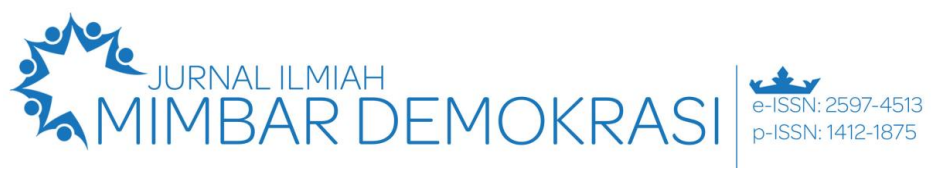

Vol. 20 No. 1 Tahun 2020 | Hal. 11 - 21

pendidikan dengan menggunakan sistem zonasi dalam PPDB, maka peneliti tertarik untuk mengambil judul 'Implemetasi Permendikbud No. 44 Tahun 2019 Tentang Sistem Zonasi Pada Penerimaan Peserta Didik Baru Jenjang Sekolah Menengah Pertama", fokus penelitian yang dilakukan oleh peneliti adalah sebagai berikut: 1) Bagaimana mekanisme pelaksanaan PPDB di Kota Tangerang Selatan dengan diterapkannya sistem zonasi sesuai dengan Permendikbud No. 44 Tahun 2019, 2) Kendala apa saja yang terjadi pada PPDB dengan sistem zonasi tahun ajaran 2020-2021 di Kota Tangerang Selatan, 3) Upaya apa saja yang dilakukan pemerintah daerah dan dinas pendidikan Kota Tangerang Selatan dalam mengatasi kendala dalam implementasi Permendikbud tersebut.

\section{Metode}

Penelitian ini dilaksanakan pada sekolah negeri di Kota Tangerang Selatan antara bulan Mei sampai dengan bulan Juli 2020. Metode yang digunakan dalam penelitian ini menggunakan pendekatan kualitatif dengan penelitian studi kasus. Pengumpulan data dilakukan dengan menggunakan wawancara, observasi dan dokumentasi. Dari data yang diperoleh kemudian dianalisis dengan kondensasi, penyajian data dan verifikasi data. Pengecekan keabsahan data dengan menggunakan uji kredibilitas (triangulasi teknik, triangulasi sumber serta memberchek). Tahapan penelitian yakni pra penelitian, pra lapangan, kegiatan di lapangan, selanjutnya menganalisis data yang diperoleh.

\section{Hasil dan pembahasan \\ Implementasi Permendikbud No. 44 Tahun 2019 tentang sistem zonasi pada PPDB di Kota Tangerang Selatan}

Sistem zonasi merupakan kebijakan publik yang diterapkan pemerintah melalui peraturan Menteri Pendidikan dan Kebudayan, namun dalam pelaksanaan di daerah disesuaikan dengan kondisi dan keadaan dari geografis, ekonomi, dan sosial masing-masing daerah, sehingga dalam pelaksanaanya pemerintah daerah menerbitkan kembali peraturan sistem zonasi ini. Kebijakan publik menurut Thomas Dye (dalam subarsono, 2005:2) adalah apapun pilihan pemerintah untuk melakukan atau tidak melakukan (public policy is whatever governments choose to do or not to do). Konsep tersebut sangat luas kebijakan publik mencakup sesuatu yang tidak dilakukan oleh pemerintah di samping yang dilakukan oleh pemerintah ketika pemerintah menghadapi suatu masalah publik. Definisi kebijakan publik dari Thomas Dye tersebut mengandung makna bahwa (1) kebijakan publik tersebut dibuat oleh badan pemerintah, bukan organisasi swasta, (2) kebijakan publik menyangkut pilihan yang harus dilakukan atau tidak dilakukan oleh badan pemerintah. (Hasanuddin \& Sopiatno, 2015). Hal ini menunjukan bahwa kebijakan publik merupakan perwujudan tindakan dan bukan merupakan pernyataan keinginan pemerintah atau pejabat publik semata. Kebijakan yang dibuat oleh pemerintah merupakan pilihan karena pada hakikatnya kebijakan tersebut mempunyai pengaruh yang berdampak pada masyarakat.

Kebijakan publik menurut Thomas Dye (2010:14), studi kebijakan publik mencakup menggambarkan upaya kebijakan publik, penilaian mengenai dampak kekuatan-kekuatan yang berasal dari lingkungan terhadap isi kebijakan publik, analisis mengenai akibat berbagai pernyataan kelembagaan dan prosesproses politik terhadap kebijakan publik; penelitian mendalam mengenai akibat-akibat dari berbagai kebijakan politik pada masyarakat, baik berupa dampak yang diharapkan (direncanakan) maupun dampak yang tidak diharapkan (Hasanuddin \& Sopiatno, 2015)

Di Kota Tangerang Selatan sendiri, untuk tingkat sekolah menegah atas negeri, sekolah menengah kejuruan negeri dan sekolah khusus negeri diatur dalam Peraturan Gubernur Banten No. 22 tahun 2020, sedangkan untuk jenjang sekolah menengah pertama dan jenjang sekolah dasar diatur mengacu pada peraturan Menteri Pendidikan dan Kebudayaan No. 44 tahun 2019 tentang penerimaan peserta didik baru pada taman kanak-kanak, sekolah dasar, seolah menegah pertama, sekolah menengah atas, dan sekolah menengah kejuruan.

Sejak tahun 2017 di Kota Tangerang Selatan diberlakukannya kebijakan pemerintah mengenai sistem zonasi pada PPDB, pelaksana pendidikan terus berupaya untuk menyelenggarakan PPDB sebaik mungkin sesuai dengan kebijakan yang berlaku. Di tengah berbagai macam problematika yang terjadi, dinas Pendidikan dan pelaksana pendidikan Kota Tangerang Selatan terus berupaya memberikan pelayanan prima kepada masyarakat, khususnya calon peserta didik baru dalam mengikuti 
serangkaian proses PPDB sistem zonasi. Pelaksanaan PPDB dengan menggunakan sistem zonasi yang diselenggarakan pada tahun 2020 di Kota Tangerang Selatan dijalankan dalam rangka pemerataan kualitas pendidikan.

Ketika penelitian ini dilaksanakan, Menteri Pendidikan dan Kebudayaan mengeluarkan surat edaran "Mendikbud Nomor 4 Tahun 2020 tertanggal 20 Maret 2020," berkaitan dengan pelaksanaan PPDB karena sedang terjadi wabah pandemi covid 19, yang isinya sebagai berikut: Penerimaan Peserta Didik Baru (PPDB) dilaksanakan dengan ketentuan sebagai berikut:

a. Dinas Pendidikan dan sekolah diminta menyiapkan mekanisme PPDB yang mengikuti protokol kesehatan untuk mencegah penyebaran Covid-19, termasuk mencegah berkumpulnya siswa dan orang tua secara fisik di sekolah;

b. PPDB pada Jalur Prestasi dilaksanakan berdasarkan: 1) akumulasi nilai rapor ditentukan berdasarkan nilai lima semester terakhir; dan/ atau 2) prestasi akademik dan non-akademik di luar rapor sekolah;

c) Pusat Data dan Informasi (Pusdatin) Kementerian Pendidikan dan Kebudayaan menyediakan bantuan teknis bagi daerah yang memerlukan mekanisme PPDB daring." (Nasional, 2020).

"Pada dasarnya sistem zonasi diselenggarakan atas dasar pembagian wilayah yang disepakati antara pihak sekolah negeri, dinas pendidikan dan pemerintah daerah untuk pengelolaannya. Penerapan sistem zonasi pada PPDB akan berimplikasi pada pudarnya status sekolah unggulan atau sekolah favorit yang menyebabkan adanya kasta dalam sistem persekolahan di Indonesia. Hal ini memberi konsekuensi bahwa pemerintah harus menyiapkan sistem pengelolaan dan penyelenggaraan layanan pembelajaran yang merata mutunya berdasarkan standar mutu yang ditetapkan dalam Standar Nasional Pendidikan (SNP). Dengan demikian, pelaksanaan Sistem Zonasi pada PPDB memberi konsekuensi akan perlunya konsep dan rumusan Sistem Zonasi Mutu Pendidikan sebagai pasangannya." (PDSPK Kemendikbud, 2018). Hal ini bertujuan untuk pemerataan kualitas dan mutu pendidikan di kota Tangerang Selatan lebih cepat.

Sistem zonasi PPDB dan Zonasi Mutu Pendidikan bertujuan untuk:
1) Menjamin penerimaan peserta didik baru berjalan secara objektif, transparan, akuntabel, nondiskriminatif, dan berkeadilan dalam rangka mendorong peningkatan akses layanan pendidikan.

2) Menjamin ketersediaan dan kesiapan satuan pendidikan (sekolah negeri, khususnya) untuk dapat memberikan layanan pendidikan yang berkualitas.

3) Menjamin adanya pemerataan akses dan mutu pendidikan yang berkeadilan pada setiap zona/wilayah yang ditetapkan mendekati tempat tinggal peserta didik.

4) Memastikan terpenuhinya tenaga pendidik dan kependidikan yang kompeten didukung oleh prasarana dan sarana yang memadai yang dapat disediakan dan digunakan bersama oleh setiap satuan pendidikan yang ada di wilayan/zona yang telah ditetapkan.

5) Mengendalikan dan menjamin mutu lulusan serta melakukan pengawasan proses dan hasil pembelajaran secara komparatif dan kompetitif pada wailayah/zona layanan pendidikan secara terukur dan berkesinambungan (PDSPK Kemendikbud, 2018).

Untuk mendapatkan wilayah zonasi yang tepat, maka pemerintah daerah sudah mengintegrasikan peraturan terkait PPDB dengan sistem zonasi secara umum yang mengacu pada peraturan pemerintah pusat yang disesuaikan dengan kondisi yang ada di wilayah kota Tangerang Selatan. Dengan dibentuknya wilayah zonasi ini, maka diharapkan peningkatan intervensi mutu dan kualitas pendidikan akan tercapai. Secara keseluruhan, petunjuk teknis pelaksanaan PPDB yang dikeluarkan oleh pemerintah Kota Tangerang Selatan sudah sesuai, karena mengacu pada Permendikbud No. 44 tahun 2020, namun dalam pelaksanaannya, masih terdapat kendala, karena masih ada beberapa wali murid yang bersikukuh dengan nilai akhir untuk dapat masuk sekolah negeri yang diinginkannya, tanpa melihat jarak antara sekolah dengan domisilinya, karena stigma sekolah favorit dan tidak favorit yang terlanjur melekat. Padahal dalam Permendikbud No. 44 ini sudah jelas diatur, bawa PPDB sistem zonasi memprioritaskan jarak domisili yang terdekat dengan sekolah, kemudian usia, nilai, atau kalau ada prestasinya, perpindahan orang tua, dan surat

14 | Jurnal Ilmiah Mimbar Demokrasi 


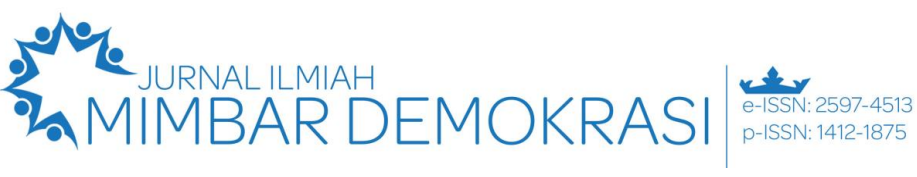

\section{Vol. 20 No. 1 Tahun 2020 | Hal. 11 - 21}

keterangan tidak mampu (PDSPK Kemendikbud, 2018).

Diketahui bahwa PPDB tahun ajaran 2020-2021 tingkat SMP negeri terdapat dua tahapan. Tahap pertama jalur zonasi, afirmasi dan perpindahan orang tua calon murid yang dibuka sejak tanggal 16 Juni 2020 sampai dengan tanggal 20 Juni 2020, dengan pengumuman penerimaan tanggal 26 Juni 2020, sedangkan tahap kedua PPDB tahun ajaran 2020-2021 dibuka dengan jalur prestasi akademik maupun prestasi olahraga sejak 30 Juni 2020 hingga 2 Juli 2020 dengan pengumuman siswa yang diterima tanggal 6 Juli 2020.

Hal ini dilakukan agar tujuan dari dilaksanakannya permendikbud ini adalah untuk pemerataan akses dan pendidikan yang berkeadilan pada setiap zona/wilayah yang ditetapkan mendekati tempat tinggal peserta didik. Penerapan sistem zonasi ini dimaksudkan untuk menghilangkan persepsi dan anggapan sekolah favorit dan tidak favorit, sehingga kualitas dan mutu pendidikan akan merata di setiap daerah.

Untuk pelaksanaan PPDB yang dilaksanakan di Kota Tangerang Selatan pada tahun ajaran 2020-2021 sudah dilaksanakan sesuai dengan petunjuk teknis yang mengacu pada keputusan Gubernur Banten No. 22 tahun 2020 tentang PPDB dan Permendikbud No. 44 Tahun 2019. Hal ini terlihat dari jalur-jalur pendaftaran yang dilakukan secara terbuka, objektif dan transparan, serta tidak adanya unsur diskriminatif. Adapun yang menjadi ukuran pelaksanaan PPDB Zonasi adalah capaian jarak dan mutu input siswa yang diterima di sekolah yang bersangkutan. Dalam pasal 11 (1) Pendaftaran PPDB dilaksanakan melalui jalur sebagai berikut: a. zonasi; b. afirmasi; c. perpindahan tugas orang tua/wali; dan/atau d. prestasi. Dalam Pasal 11 ayat (2), (3), dan (4) Jumlah siswa yang diterima sebanyak $50 \%$ berdasarkan jarak terdekat dengan domisili, sedangkan $15 \%$ diperuntukan untuk calon peserta didik dengan menggunakan jalur afirmasi, baik itu secara akademik maupun non akademik, sedangkan sisanya untuk jalur yang berkebutuhan khusus, siswa yang terdampak bencana, perpindahan orang tua, dan lain sebagainya (Mendikbud, 2019).

Domisili calon peserta didik didasarkan alamat pada kartu keluarga yang diterbitkan paling singkat 1 (satu) tahun sejak tanggal pendaftaran PPDB. Untuk kartu keluarga dapat diganti dengan surat keterangan domisili dari rukun tetangga atau rukun warga yang dilegalisir oleh lurah/kepala desa atau pejabat setempat lain yang berwenang menerangkan bahwa peserta didik yang bersangkutan telah berdomisili paling singkat 1 (satu) tahun sejak diterbitkannya surat keterangan domisili. Sekolah memprioritaskan peserta didik yang memiliki kartu keluarga atau surat keterangan domisili dalam satu wilayah kabupaten/kota yang sama dengan Sekolah asal. Selain melakukan pendaftaran PPDB melalui jalur zonasi sesuai dengan domisili dalam wilayah zonasi yang telah ditetapkan, calon peserta didik dapat melakukan pendaftaran PPDB melalui jalur afirmasi atau jalur prestasi di luar wilayah zonasi domisili peserta didik sepanjang memenuhi persyaratan (Mendikbud, 2019).

Untuk calon peserta didik yang menggunakan jalur afirmasi hanya diperuntukkan bagi Peserta Didik yang berasal dari keluarga ekonomi tidak mampu. Peserta didik baru yang berasal dari keluarga ekonomi tidak mampu dibuktikan dengan bukti keikutsertaan orang tua/ Peserta didik dalam program penanganan keluarga tidak mampu dari Pemerintah Pusat atau Pemerintah Daerah. Peserta didik yang masuk melalui jalur afirmasi merupakan Peserta didik yang berdomisili di dalam dan di luar wilayah zonasi Sekolah yang bersangkutan. Bukti keikutsertaan dalam program penanganan keluarga tidak mampu dari Pemerintah Pusat atau Pemerintah Daerah wajib dilengkapi dengan surat pemyataan dari orang tua/wali Peserta didik yang menyatakan bersedia diproses secara hukum apabila terbukti memalsukan bukti keikutsertaan dalam program penanganan keluarga tidak mampu dari Pemerintah Pusat atau Pemerintah Daerah. Apabila ditemukan data pemalsuan bukti keikutsertaan dalam program penanganan keluarga tidak mampu dari Pemerintah Pusat atau Pemerintah Daerah Sekolah wajib melakukan verifikasi data dan lapangan serta menindaklanjuti hasil verifikasi sesuai dengan ketentuan perundangundangan (Negeri et al., 2020).

Secara langsung maupun tidak langsung, dampak dari adanya zonasi ini akan memotivasi guru untuk mengajar lebih ekstra dalam menyampaikan ilmunya kepada siswa, karena ketika masuk sekolah nilai skor tidak diperhitungkan, untuk menghadapi berbagai macam kemampuan siswa tersebut solusinya adalah, guru memberikan jam tambahan khusus bagi siswa yang memiliki kemampuan di bawah rata-rata agar mereka dapat mengejar ketertinggalan dari teman-temannya. Untuk itu kepala sekolah akan memberikan penilaian yang 
baik atas kinerja yang dilakukan oleh para guru ini. 'Kepala sekolah memperhatikan iklim yang ada pada organisasi sekolah merupakan suatu gambaran bahwa pencapaian tujuan organisasi sekolah juga akan banyak ditentukan oleh bagaimana pengelolaan lingkungan sekolah sebagai pembentuk iklim organisasi sekolah, mendorong pada situasi yang kondusif bagi guru dan staf lainnya untuk melaksanakan tugasnya secara optimal.” (Manullang \& Sibuea, 2017).

Kegiatan pelaksanaan PPDB di Kota Tangerang Selatan melibatkan perwakilan dari dinas pendidikan, kepala sekolah, guru, komite sekolah yang bertugas sesuai dengan perannya masing-masing, mulai dari perencanaan, pelaksanaan, dan pegawasan kegiatan pendaftaran PPDB, baik itu secara online maupun secara offline. Selain itu juga kegiatan ini melibatkan masyarakat yang diwakili oleh orang tua murid/wali murid, serta calon peserta didik sebagai sasaran dari penerapan kebijakan pelaksanaan PPDB di lapangan. Selain sumber daya manusia yang sudah disebutkan tadi, pelaksanaan PPDB di Kota Tangerang Selatan juga melibatkan sumber daya non manusia, yakni didukung oleh peralatan memadai yang disediakan oleh pihak sekolah. Dari segi pelaksanaan pun PPDB telah sesuai dengan jadwal yang ditetapkan.

Dari pemantauan penulis, dalam menjalankan tugasnya, pihak penyelenggara, baik itu di sekolah maupun dari dinas pendidikan Kota Tangerang Selatan sudah membentuk tim khusus sesuai dengan keahliannya, baik itu ketika pendaftaran online maupun ketika pendaftaran offline. Secara umum, pelaksanaan PPDB di Kota Tangerang Selatan sudah dilaksanakan sesuai dengan aturan dan ketentuan juknis PPDB TK, SD, SMP, SMA dan SMK tahun ajara 2020-2021 yang diatur dalam Permendikbud Nomor 44 Tahun 2019, dimana pelaksanaan nya didasarkan pada asas keadilan, non diskriminatif, kecuali di sekolah khusus yang hanya melayani peserta didik dari kelompok gender atau agama tertentu, transparan, akuntabel dan objektif.

Secara umum, pelaksanaan PPDB di Kota Tangerang Selatan tidak mengalami kendala yang berarti, hal ini dikarenakan komunikasi yang terjalin dengan baik antara pihak penyelenggara dengan dinas pendidikan serta dengan wali murid. Dari wawancara penulis dengan beberapa wali calon murid, kendala teknis yang biasanya dialami oleh mereka adalah hanya ada pada penggunaan jaringan internet dan domisili siswa yang letaknya di luar kelurahan yang berbeda, namun lebih dekat dengan letak sekolahan yang berbeda dengan kelurahan tempat domisili calon siswa tersebut berada. Dalam hal ini, kebijakan yang diberikan adalah memberikan ijin masuk pada sekolah yang lebih dekat.

Dari segi ekonomi, PPDB dianggap menguntungkan, karena dalam pelaksanaannya tidak dipungut biaya pendaftaran, ini akan menguntungkan bagi calon siswa yang tergolong kurang mampu, selain itu, dengan PPDB akan menghemat pengeluaran wali siswa dalam pengeluaran sehari-hari, karena tidak perlu mengeluarkan biaya untuk transportasi untuk akomodasi ke sekolah. Hal ini tentu saja berdampak positif bagi perekonomian wali murid. Dari segi sosial, tangggapan masyarakat, dalam hal ini wali murid tampak beragam, ada yang merasa sangat diuntungkan, ada juga yang merasa dirugikan. Banyak wali murid yang memberikan respon negatif dengan diberlakukannya sistem zonasi ini karena dianggap membingungkan. Dengan adanya respon seperti ini, mengindikasikan bahwa banyak wali murid yang belum siap dengan kebijakan ini.

\section{Hambatan-hambatan pelaksanaan PPDB di Kota Tangerang Selatan}

Walaupun pihak penyelenggara dan petugas sudah menjalankan tugasnya sesuai dengan ketentuan, tidak semua pihak merespon positif dengan adanya ketentuan zonasi dalam PPDB ini. Hal ini ditunjukan oleh sikap wali murid yang tidak sepenuhnya mendukung diberlakukannya kebijakan ini, mereka menganggap hak mereka dalam memilih sekolah yang diinginkan dibatasi oleh kebijakan permendikbud. Banyak wali murid yang beranggapan bahwa prestasi bagus yang diraih oleh anak-anaknya dianggap tidak berharga, sehingga mereka melakukan protes dengan kebijakan ini, karena kalah bersaing untuk masuk sekolah yang diinginkan dengan calon siswa lain yang memiliki prestasi biasa-biasa saja hanya karena jarak domisilinya di luar jalur 1 yang sudah ditetapkan.

Pelaksanaan kebijakan PPDB di kota Tangerang Selatan pada umumnya sudah berjalan dengan efektif, walaupun kendala-kendala kecil memang tidak bisa dihindari. Hal ini dikarenakan masih ada beberapa calon wali peserta didik yang belum memahami diberlakukannya kebijakan Permendikbud No 44 Tahun 2019 tentang sistem zonasi dalam PPDB. 'Proses kebijakan publik berlangsung dalam suatu sistem politik yang dipengaruhi oleh lingkungannya. Input kebijakan berasal dari lingkungan dalam bentuk tuntutan 


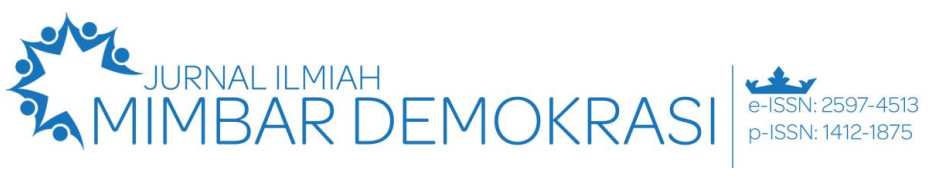

Vol. 20 No. 1 Tahun 2020 | Hal. 11 - 21

politis, yang berkembang menjadi isu kebijakan yang diproses sampai akhirnya menjadi keputusan kebijakan. Demikian pula proses kebijakan pendidikan, sebagai bagian dari kehidupan kenegaraan, maka juga tidak dapat dilepaskan dari sistem politik dan lingkungannya. Proses kebijakan pendidikan ini berjalan secara bertahap, dan sirkuler (siklikal) sehingga suatu kebijakan tidak dapat dilepaskan dari kebijakan-kebijakan lain yang sudah ada atau kebijakan yang sedang berjalan (Hough, 1984: 17; Dunn, 2004: 46; Fowler, 2009: 14-18, Wibowo, 2013).

Kendala yang dihadapi pada implementasi kebijakan sistem zonasi adalah kekurang pahaman wali murid terhadap sosialisasi yang sudah dilaksanakan oleh berbagai pihak, termasuk oleh dinas pendidikan setempat. Kekurang pahaman wali murid ini bisa jadi dikarenakan latar belakang pendidikan dan sosial ekonomi yang berbeda. 'Kebijakan merupakan hasil dari politik, atau hasil dari alokasi nilai, yakni apa yang dipilih pemerintah untuk dikerjakan, termasuk untuk tidak dikerjakan. Sehubungan dengan itu kebijakan (termasuk kebijakan pendidikan) merupakan perangkat operasional, atau pedoman-pedoman bagi pemerintah untuk melaksanakan keputusan-keputusan yang ditetapkan oleh lembaga politik. Dengan merujuk pendapat pakar (Kerr, 1976; Wildavsky, 1979; MacRae dan Wilde, 1985) dapat disimpulkan bahwa kebijakan pendidikan adalah serangkatan keputusan dan/atau tindakan pemerintah yang memiliki tujuan khusus untuk menyelesaikan permasalahan atau urusan di bidang pendidikan dan hasilnya memiliki dampak terhadap orang banyak. Sehubungan dengan itu kebijakan pendidikan perlu disusun secara cermat, jelas dan tegas guna mengatur penyelenggaraan pendidikan sehingga dapat meningkatkan kinerja pendidikan nasional." (Wibowo, 2013).

$$
\text { Richard E. Matland }
$$

mengembangkan Model Matriks AmbiguitasKonflik untuk menjelaskan bahwa implementasi secara admiministratif adalah implementasi yang dilakukan dalam keseharian operasi birokrasi pemerintahan. Kebijakan di sini memiliki ambiguitas atau kemenduaan yang rendah dan konflik yang rendah. Implementasi secara politik adalah implementasi yang perlu dipaksakan secara politik, karena walaupun ambiguitasnya rendah, tingkat konfliknya tinggi. Implementasi secara eksperimen dilakukan pada kebijakan yang mendua, namun tingkat konfilknya rendah. Implementasi secara simbolik dilakukan pada kebijakan yang mempunyai ambiguitas tinggi dan konflik yang tinggi. Menurut Matland: Pada prinsipnya matriks memiliki empat tepat yang perlu dipenuhi dalam hal keefektifan implementasi kebijakan, yaitu:

Pertama: Ketepatan Kebijakan.

Ketepatan kebijakan dinilai dari tiga hal, yaitu:

1) Sejauh mana kebijakan yang ada telah bermuatan hal-hal yang memang memecahkan masalah yang hendak dipecahkan. Pertanyaannya adalah how excelent is the policy.

2) Apakah kebijakan tersebut sudah dirumuskan sesuai dengan karakter masalah yang hendak dipecahkan.

3) Apakah kebijakan dibuat oleh lembaga yang mempunyai kewenangan (misi kelembagaan) yang sesuai dengan karakter kebijakan.

Kedua: Ketepatan Pelaksana.

Aktor implementasi kebijakan tidaklah hanya pemerintah. Ada tiga lembaga yang bisa menjadi pelaksana, yaitu:

1) Pemerintah.

Kebijakan-kebijakan yang bersifat monopoli, seperti kartu identitas penduduk, atau mempunyai derajat politik keamanan yang tinggi, seperti pertahanan dan keamanan, sebaiknya diselenggarakan oleh pemerintah.

2) Kerjasama antara pemerintah-masyarakat/swasta.

Kebijakan yang bersifat memberdayakan masyarakat, seperti penanggulangan kemiskinan, sebaiknya diselenggarakan pemerintah bersama masyarakat/swasta.

3) Implementasi kebijakan yang diswastakan (privatization atau contracting out).

Kebijakan yang bertujuan mengarahkan kegiatan-kegiatan masyarakat, seperti bagaimana perusahaan harus dikelola, atau dimana pemerintah tidak efektif menyelenggarakannya sendiri, seperti pembangunan industri-industri berskala menengah dan kecil yang tidak strategis, sebaiknya diserahkan kepada masyarakat.

Ketiga: Ketepatan Sasaran.

Ketepatan sasaran (target) berkenaan dengan tiga hal, yaitu:

1) Apakah target yang diintervensi sesuai dengan yang direncanakan, apakah tidak ada tumpang tindih dengan intervensi 
lain, atau tidak bertentangan dengan intervensi kebijakan lain.

2) Apakah targetnya dalam kondisi siap untuk diintervensi ataukah tidak. Kesiapan bukan saja dalam arti secara alami, namun juga apakah kondisi target ada dalam konflik atau harmoni, dan apakah kondisi target ada dalam kondisi mendukung atau menolak.

3) Apakah intervensi implementasi kebijakan bersifat baru atau memperbarui implementasi kebijakan sebelumnya.

Terlalu banyak kebijakan yang tampaknya baru namun pada prinsipnya mengulang kebijakan yang lama dengan hasil yang sama tidak efektifnya dengan kebijakan sebelumnya.

Keempat: Ketepatan Lingkungan.

Ada dua lingkungan yang paling menentukan, yaitu:

1) Lingkungan Kebijakan.

Lingkungan kebijakan menyangkut interaksi antara lembaga perumus kebijakan dengan pelaksana pelaksana kebijakan dan dengan lembaga yang terkait. Donald J. Calista menyebut- nya sebagai variabel endogen, yaitu authoritative arrangement yang berkenaan dengan kekuatan sumber otoritas dari kebijakan, network composition yang berkenaan dengan komposisi jejaring dari berbagai organisasi yang terlibat kebijakan, baik dari pemerintah maupun masyarakat, implementation setting yang berkenaan dengan posisi tawar-menawar antara otoritas yang mengeluarkan kebijakan dan jejaring yang berkenaan dengan implementasi kebijakan.

2) Lingkungan Eksternal Kebijakan.

Lingkungan ini oleh Calista disebut sebagai variabel eksogen, yang terdiri dari public opinion, yaitu persepsi publik akan kebijakan dan implementasi kebijakan, interpretive institutions yang berkenaan dengan interprestasi lembaga-lembaga strategis dalam masyarakat, seperti media massa, kelompok penekan, dan kelompok kepentingan, dalam menginterpretasikan kebijakan dan implementasi kebijakan, dan individuals, yakni individu-individu tertentu yang mampu memainkan peran penting dalam menginterpretasikan kebijakan dan implementasi kebijakan (Purwanti et al., 2019).

Banyaknya wali murid yang memaksa pihak penyelenggara PPDB agar menerima anaknya masuk ke sekolah yang diinginkan menjadi kendala tersendiri bagi pihak penyelenggara, selain itu juga biasanya pihak sekolah mendapatkan berbagai macam titipan dari pejabat-pejabat, dari kenalan dekat, wartawan, LSM, atau dari pihak lainnya agar anaknya bisa masuk sekolah yang bersangkutan.

Hal ini telah diungkapkan oleh Fawler (2004:273), bahwa: "implementer frequently do not understand what they are supposed to do, yang artinya bahwa implementor seringkali tidak tahu apa yang seharusnya dilakukan. Hal ini bisa disebabkan karena kurangnya sosialisasi, pengarahan serta bimbingan mengenai implementasi kebijakan zonasi kepada wali murid. Selain itu kendala secara teknis yaitu daya tampung server yang masih agak kurang untuk bisa diakses secara bersamaan di seluruh wilayah, sehingga mempengaruhi kecepatan saat mengakses halaman website" (Purwanti et al., 2019).

Hambatan yang berikutnya adalah daya tampung sekolah negeri yang masih kurang memenuhi kebutuhan jumlah lulusan, sehingga banyak masyarakat yang merasa nilainya bagus diperlakukan tidak adil dengan adanya sistem zonasi ini. Wali murid dan calon siswa merasa sia-sia berupaya meraih nilai bagus, tetapi tidak bisa masuk sekolah negeri yang diinginkannya, hingga hal ini menjadi pergunjingan di antara para wali murid, daripada membayar uang untuk les tambahan, lebih baik uangnya dipakai ngontrak rumah sekitar sekolah yang diinginkan selama 1 tahun sebelum PPDB dibuka agar mendapatkan prioritas masuk sekolah yang diinginkan. Selain hambatan tadi, banyaknya wali murid yang menggunakan surat keterangan tidak mampu (SKTM) sebagai senjata untuk masuk sekolah yang diinginkan. Hal ini sangat merugikan calon peserta didik lain yang memang benar-benar membutuhkan, dan benar-benar berada di dalam jalur 1 yang diprioritaskan masuk sekolah negeri. Sabatier dan Mazmanian menegaskan bahwa "implementasi kebijakan berarti mewujudkan suatu keputusan kebijakan yang memiliki legalitas hukum dapat berbentuk undang-undang, peraturan pemerintah, keputusan eksekutif, dan lain- lain dalam bentuk program-program kerja yang merujuk pada masalah yang akan ditangani oleh kebijakan." (Purwanti et al., 2019). 


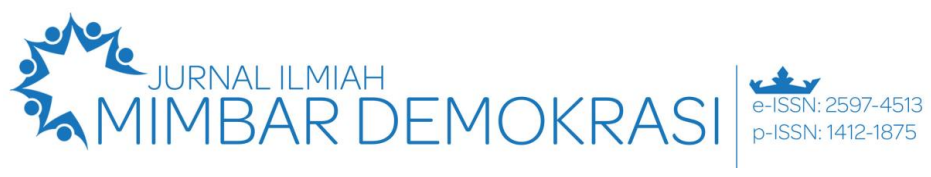

\section{Vol. 20 No. 1 Tahun 2020 | Hal. 11 - 21}

Berbagai macam cara yang dilakukan oleh wali murid agar anaknya bisa masuk sekolah favorit yang diinginkan, persepsi ini harus dihilangkan karena dengan diberlakukannya permendikbud tentang sistem zonasi dalam PPDB akan merubah persepsi sekolah favorit dan tidak favorit sehingga kualitas dan mutu pendidikan baik di kota besar maupun di daerah akan sama.

\section{Upaya mengatasi kendala yang timbul dalam pelaksanaan PPDB}

Timbulnya permasalahan-permasalahan yang muncul dalam pelaksanaan PPDB ini menjadikan pemerintah dan pihak penyelenggara melakukan berbagai macam cara untuk meminimalisisr hambatan-hambatan dalam pelaksanaan proses pendidikan di lapangan. Salah satu cara yang diupayakan oleh pemerintah dalam pemerataan kualitas pendidikan adalah dengan memberlakukan sistem zonasi ini. Dengan sistem zonasi, diharapkan tidak ada lagi dikotomi sekolah favorit dan tidak favorit. Dengan adanya sistem zonasi akan membantu pemerintah dalam melakukan pemetaan anggaran pendidikan, populasi siswa, dan tenaga pendidik.

Selain itu, upaya yang dilakukan untuk mengatasi permasalahan secra teknis yakni dengan meningkatkan daya tampung server dengan cara mengupdate atau memperkuat servernya. Dalam mengatasi permasalahanpermasalahan yang timbul ini, harus sesuai dengan standar operasional yang berlaku.

Terkait dengan adanya respon positif dan negatif dari masyarakat berkenaan dengan pemberlakuan permendikbud ini, maka ada baiknya pemerintah melakukan solusi perbaikan, di antaranya, pertama sebelum kebijakan ini diimplementasikan di masyarakat, pemerintah terutama daerah harus melakukan sosialisasi secara masif kepada masyarakat, jauh sebelum pelaksanaan PPDB ini dilaksanakan agar masyarakat mampu memahami kebijakan ini secara kompherensif, karena pada dasarnya kebijakan itu dibuat demi untuk kepentingan masyarakat luas, dan demi meningkatnya kualitas pendidikan di Indonesia (Purwanti et al., 2019).

Yang kedua adalah, pemerintah harus memperhitungkan daya tampung sekolah setiap zonasi dengan jumlah lulusan yang dihasilkan, pemerintah juga harus mempertimbangkan kebutuhan ini, karena bisa dimungkinkan terjadi, satu zona banyak jumlah sekolah negerinya, tapi lulusannya tidak banyak, tapi di zona lainnya kekurangan sekolah negeri, tetapi lulusannya melebihi kapasitas atau daya tampung sekolah yang ada. Oleh karena itu pemerintah daerah harus mengevaluasi kembali proyeksi lulusan sekolah, sehingga dapat membandingkan antara sekolah yang tersedia dengan daya tampung lulusan untuk menentukan zonasi, agar masyarakat mendapat kelonggaran untuk mendaftarkan ke sekolah yang belum terpenuhi kuota peserta didiknya.

Yang ketiga adalah perlu adanya kebijakan dari lembaga-lembaga terkait berkenaan dengan surat keterangan tidak mampu (SKTM) yang dapat dijadikan rujukan agar diterima dalam PPDB. Banyaknya kasus menggunakan SKTM palsu seringkali dijadikan alat untuk rekomendasi masuk ke sekolah negeri yang diinginkan. Namun SKTM pada tahun ajaran ini dinyatakan tidak berlaku lagi, karena untuk jalur afirmasi, peserta didik baru yang berasal dari keluarga ekonomi tidak mampu dibuktikan dengan bukti keikutsertaan orang tua/Peserta didik dalam program penanganan keluarga tidak mampu dari Pemerintah Pusat atau Pemerintah Daerah. Bukti keikutsertaan dalam program penanganan keluarga tidak mampu dari Pemerintah Pusat atau Pemerintah Daerah wajib dilengkapi dengan surat pemyataan dari orang tua/wali Peserta didik yang menyatakan bersedia diproses secara hukum apabila terbukti memalsukan bukti keikutsertaan dalam program penanganan keluarga tidak mampu dari Pemerintah Pusat atau Pemerintah Daerah.

Keempat, pemerintah harus mampu mengubah persepsi dari para wali murid tentang persepsi sekolah favorit dan sekolah bukan favorit, karena ke depannya, dengan diberlakukan sistem zonasi dalam PPDB maka predikat tersebut akan hilang. Menurut Leavit dalam Sobur (2003: 445), "persepsi dalam arti sempit adalah penglihatan, bagaimana cara seseorang melihat sesuatu, sedangkan dalam arti luas persepsi adalah pandangan atau pengertian yaitu sebagaimana seseorang memandang atau mengartikan sesuatu." Sementara M Husaini dan M. Noor (1981:103) menyatakan bahwa "persepsi merupakan obyek di sekitar yang ditangkap dan proyeksi pada bagian tertutup dalam otak sehingga kita dapat mengamati obyek tersebut. Persepsi adalah tanggapan yang didapat dari pengamatan oleh panca indera manusia, yang juga berhubungan dengan nilai-nilai kebenaran yang dianut oleh seseorang serta berpengaruh pada sikap yang nantinya akan diambil olehnya. Persepsi ini juga biasanya didapatkan dari pengalaman orang lain yang menilai akan suatu kualitas dan kuantitas dari pelayanan dan hasil yang 
diberikan oleh suatu lembaga tertentu, begitu juga dengan penilaian seorang wali murid yang pernah mendaftarkan anaknya ke sekolah yang dianggap favorit." (Anggraini \& Oliver, 2019). Dari sini mereka akan saling berbagi pengalaman kepada wali murid lainnya, dan ini akan mempengaruhi pola pikir orang tua dalam memilih sekolah favorit untuk anak-anaknya, karena pada hakikatnya orang tua menginginkan anaknya mendapatkan pendidikan yang terbaik.

\section{Simpulan}

Fokus utama dari pemerintah Kota Tangerang Selatan dalam meningkatkan kualitas pendidikan bagi warganya adalah membangun pendidikan yang berkualitas untuk jangka panjang yang mengacu kepada standar pendidikan nasional, yakni standar kompetensi lulusan, standar isi, standar proses, standar pendidikan dan tenaga kependidikan, standar sarana dan prasarana, standar pengelolaan, dan standar pembiayaan pendidikan. Implementasi kebijakan PPDB di Kota Tangerang Selatan pada umumnya sudah berjalan dengan baik, hal ini dibuktikan bahwa penyelenggaraan PPDB, sesuai dengan aturan dan ketentuan yang mengacu pada Permendikbud No. 44 tahun 2020 dan Peraturan Gubernur Banten Nomor 22 Tahun 2020 tentang PPDB pada Sekolah Menengah Atas, Sekolah Menengah Kejuruan dan Sekolah Khusus Negeri di Provinsi Banten. Kendala kecil terjadi hanya pada wali murid yang masih kurang memahami akan kebijakan yang diberlakukan dalam PPDB dan kendala server yang masih lambat karena digunakan secara bersamaan. Pada umumnya ukuran tujuan dari kebijakan ini sudah memberikan dampak yang positif, baik bagi siswa maupun bagi pihak sekolah. Sumber daya pelaksana PPDB juga sudah cukup memadai dan mematuhi peraturan yang ditetapkan oleh dinas pendidikan setempat. Anggaran yang digunakan dalam PPDB ini berasal dari dana bantuan operasional sekolah dan rancangan anggaran kegiatan sekolah. Partisipasi dari pelaksana dan komunikasi juga sudah berjalan dengan cukup baik, selain itu dilihat dari segi ekonomi, sosial dan politik, kebijakan PPDB ini memberikan pengaruh yang cukup baik, antara sekolah dengan masyarakat. Sedangkan hambatanhambatan yang terjadi sudah teratasi dengan baik. Saran yang disampaikan oleh penulis dari adanya penelitian ini adalah: pertama perlu adanya sosialisasi tentang kebijakan Permendikbud No. 44 tahun 2019 tentang sistem zonasi dalam PPDB sedini mungkin sebelum pelaksanaan PPDB dilaksanakan, kedua pemerintah daerah, dinas pendidikan dan pihak sekolah seyogyanya mampu meningkatkan kekuatan server agar tidak terjadi kekecewaan pada pengguna ketika harus bersama sama menggunakan server. Selain itu juga wali atau orang tua murid juga harus menyadari bahwa dengan diberlakukannya sistem zonasi ini akan meningkatkan pemerataan kualitas dan mutu pendidikan di Indonesia.

\section{Ucapan Terima kasih}

Penulis mengucapkan terima kasih kepada Direktorat Jendral Penguatan Riset dan Pengembangan Kementrian Riset Teknologi dan Pendidikan tinggi (Kemenristekdikti) yang telah mendanai penelitian tahun 2020 dalam skema penelitian dosen pemula (PDP), juga kepada pihak-pihak yang telah membantu terlaksananya penelitian ini.

\section{Referensi}

Anggraini, A. R., \& Oliver, J. (2019). Effects of Motivational Beliefs and Instructional Practice on Students' Intention to Pursue Majors and Careers in Engineering. J. Chem. Inf. Model, 53(9), 1689-1699.

Dunn, W. (2004). Public Policy Analysis: An Introduction (Third Ed.). New Jersey: Pearson - Prentice Hall Inc.

Dye, Thomas R. (2005). Understanding Public Policy. (Thirteen Ed.). New Jersey: Pearson Prentice Hall.

Fowler, F.C. (2009). Policy Studies for Educational Leaders: An Introduction (Third Ed.). Boston: Pearson Education, Inc.

Hasanuddin, H., \& Sopiatno, B. (2015). Implementasi Kebijakan Penerimaan Peserta Didik Baru (Ppdb) Online Tingkeat Sekolah Menengah Atas di Kota Pekanbaru Tabun 2011-2013 (Doctoral dissertation, Riau University).

Hough, J.R. (1984). Educational Policy: An Internasional Survey. London-Sydney-New York: Croom Helm Ltd. And St. Martin's Press.

Manullang, Z. B., \& Sibuea, A. M. (2017). Kata Kunci: 9(2), 74-89.

Mendikbud. (2019). Penerimaan Peserta Didik Baru pada TK, SD, SMP, SMA, dan SMK. 25.

Nasional, U. (2020). C. d. 0.0075 300. 300.

Negeri, K., Provinsi, D. I., Rahmat, D., Yang, T., \& Esa, M. (2020). Gubernur banten. 6, 121. 


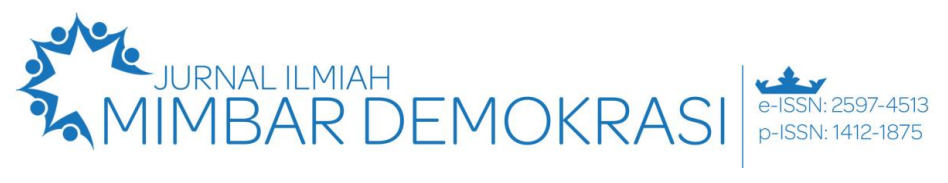

Vol. 20 No. 1 Tahun 2020 | Hal. 11 - 21

Nurjamila siregar, H. N. (2019). Uud 1945. 2, 1 19.

https://doi.org/10.31227/osf.io/s4vuy

PDSPK Kemendikbud. (2018). Profil Sistem Zonasi Penerimaan Peserta Didik Baru dan Zonasi Mutu Pendidikan. Kemendikbud RI, 24.

Purwanti, D., Irawati, I., Adiwisastra, J., \& Bekti, H. (2019). Implementasi Kebijakan Penerimaan Peserta Didik Baru Berdasarkan Sistem Zonasi Di Kota Bandung. Jurnal Governansi, 5(1), 12. https://doi.org/10.30997/jgs.v5i1.1699

Sobur, Alex. (2003). Psikologi Umum. Bandung: Pustaka Setia.

Wibowo, U. B. (2013). Intensitas Peran Aktor Kebijakan Dan Kekuatan Politis Dalam Perumusan Kebijakan Sertifikasi Pendidik. Jurnal Penelitian Ilmu Pendidikan, 6(1). 